\title{
Drug Discovery for Overcoming Chronic Kidney Disease (CKD): Pharmacological Effects of Mineralocorticoid-Receptor Blockers
}

\author{
Akira Nishiyama $^{1, *}$, Hirofumi Hitomi ${ }^{1}$, Asadur Rahman ${ }^{2}$, and Hideyasu Kiyomoto ${ }^{3}$ \\ ${ }^{1}$ Department of Pharmacology, ${ }^{3}$ Department of CardioRenal and Cerebrovascular Medicine, Faculty of Medicine, \\ Kagawa University, Kagawa 761-0793, Japan \\ ${ }^{2}$ Department of Pharmacology, Bangladesh Agricultural University, Mymensingh, Bangladesh
}

Received August 14, 2008; Accepted September 22, 2008

\begin{abstract}
There is increasing evidence demonstrating that the renoprotective effects of mineralocorticoid receptor (MR) blockade are independent of the effects exerted by reninangiotensin inhibitors. MR is expressed not only in tubular cells but also in other renal cells including glomerular mesangial cells, podocytes, and renal interstitial fibroblasts. Animal experiments have shown that MR blockers prevent aldosterone-induced proteinuria, glomerular injury, and tubulointerstitial fibrosis. In vitro studies have also demonstrated that MR blockers inhibit aldosterone-induced renal cell damage. Recent clinical studies have shown that treatment with MR blockers attenuates the development of proteinuria in patients with chronic kidney disease (CKD) and hypertension, independent of changes in blood pressure. In some cases, MR blockers elicit potent renoprotective effects in conditions where aldosterone levels are not elevated. These data suggest that treatment with MR blockers may possibly present an effective therapeutic strategy for patients with CKD.
\end{abstract}

Keywords: aldosterone, mineralocorticoid receptor (MR), eplerenone, kidney, chronic kidney disease (CKD)

\section{Introduction}

Recent studies have implicated the role of angiotensin II in mediating renal injury (1). The Seventh Report of the Joint National Committee (JNC7), the European Society of Hypertension/European Society of Cardiology (the 2003 ESH-ESC), and the Japanese Society of Hypertension (JSH2004) all recommend that angiotensinconverting enzyme (ACE) inhibitors and angiotensin IIreceptor blockers (ARBs) should be used in combination with diuretics as the first-line therapy to reduce blood pressure in hypertensive patients with chronic kidney disease (CKD) $(2-5)$. However, it has become evident that aldosterone is a key factor in mediating renal injury through both hemodynamic-dependent and independent effects $(6,7)$. Patients with primary aldosteronism, who have low angiotensin II levels, show higher incidence of proteinuria or albuminuria than patients with essential

*Corresponding author. akira@kms.ac.jp

Published online in J-STAGE

doi: $10.1254 /$ jphs.08R12FM hypertension (8, 9). Plasma aldosterone levels are positively correlated with urinary protein excretion levels (10) and negatively correlated with glomerular filtration rates (11) in patients with CKD. Animal studies have shown that chronic infusion of aldosterone in combination with high salt treatment elicits severe proteinuria, glomerular mesangial injury, and tubulointerstitial fibrosis $(12-14)$. However, these aldosteroneinduced renal injuries were prevented by treatment with the selective MR antagonist eplerenone, suggesting that aldosterone induces renal injury through locally expressed MR (12). Recent in vitro studies have also demonstrated that MR is expressed not only in distal tubular cells but also in other renal cells, which mediates aldosterone-induced renal cell injury $(6,7)$. Along with the roles of aldosterone and MR in renal injury, studies have revealed the beneficial effects of MR blockers on renal injury. In this review, we have briefly summarized some data from both preclinical and clinical studies regarding the pharmacological effects of MR blockers on renal injury. 


\section{Preclinical evidence for renoprotective effects of MR blockers}

The renoprotective effects of MR blockers have been demonstrated in a variety of animal models. In streptozotocin-induced insulin-deficient hyperglycemic rats, treatment with the non-selective MR antagonist spironolactone had minimal effect on glucose levels, but it ameliorated the development of proteinuria and renal tissue injury $(15,16)$. Similar results with spironolactone or eplerenone were obtained in type 2 diabetic rats (17), mice (18), and obese spontaneously hypertensive rats (SHR) (19). Furthermore, spironolactone and eplerenone have been shown to attenuate the progression of proteinuria, glomerular injury, and tubulointerstitial fibrosis in murine lupus nephritis (20) or in rats treated with angiotensin II and an nitric oxide synthase inhibitor (21), cyclosporine A $(22-24)$, or radiation (25). Treatment with spironolactone prevents tubulointerstitial fibrosis and tubular apoptosis in mice subjected to unilateral ureteral occlusion (26) and in rats that underwent ischemia and reperfusion (27) or $5 / 6$ nephrectomy (28). Importantly, in these animal models, treatment with MR blockers had no effect on systemic blood pressure. Thus, these observations are consistent with the concept that aldosterone and MR-dependent renal injury is not dependent on blood pressure changes but on their local actions. This concept is supported by some recent in vitro studies that have demonstrated that MR is expressed not only in distal tubular cells but also in other renal cells, including glomerular mesangial cells (29), podocytes (30), renal interstitial fibroblasts (31), and proximal tubular cells (32), which mediates aldosterone-induced renal cell injury $(6,7)$.

\section{Clinical evidence for renoprotective effects of MR blockers}

Monotherapy with spironolactone elicits blood lowering effects that are similar to those of the ACE inhibitor cilazapril, but spironolactone is more effective than cilazapril in reducing proteinuria in hypertensive patients with type 2 diabetes (33). Similarly, eplerenone is more effective in reducing albuminuria than the ACE inhibitor enalapril in hypertensive patients (34). In older patients with systolic hypertension, eplerenone has blood pressure lowering effects similar to the calcium channel antagonist amlodipine, but reduces the urinary albumin/creatinine ratio more than amlodipine (35). Collectively, these observations suggest that MR blockers have strong renoprotective effects through mechanisms that cannot be simply explained by blood pressure changes.
In some patients, plasma aldosterone levels are initially decreased by treatment with ACE inhibitors or ARBs but are increased in the long term (36), a phenomenon termed "aldosterone breakthrough". Furthermore, recent in vitro studies have reported the existence of cross-talk between aldosterone- and angiotensin II-dependent intracellular signaling pathways $(37-41)$. Therefore, targeting aldosterone with MR blockers may amplify the beneficial effects of therapy with ACE inhibitors and ARBs $(42,43)$. Indeed, several clinical studies have demonstrated that the addition of spironolactone or eplerenone to ACE inhibitors or ARBs has no effects on blood pressure but markedly reduces proteinuria in patients with diabetic nephropathy $(33,44)$ or non-diabetic CKD $(10$, 45). More recently, Bomback et al. (46) performed a systematic review of 15 clinical studies [four were parallel-group randomized controlled trials $(47-50)$; four were crossover randomized controlled trials $(33,44$, $51,52)$; two were pilot studies $(10,45)$; and five were case studies $(53-57)]$ that examined the effects of adding MR blockers to ACE inhibitors and/or ARBs on proteinuria and the risk of hyperkalemia in patients with CKD. In these studies, the reported decreases in proteinuria from baseline ranged from $15 \%-54 \%$, whereas hyperkalemic events were significant in only one of the eight randomized controlled trials. However, MR-blocker therapy was directed exclusively at proteinuric patients, most with effective glomerular filtration rates exceeding $60 \mathrm{~mL} / \mathrm{min}$ per $1.73 \mathrm{~m}^{2}$ and all with pretreatment serum potassium levels less than $5.0 \mathrm{mmol} / \mathrm{L}$. Thus, although in patients with early phase CKD, adding MR blockers to ACE inhibitors and/or ARBs yields significant decreases in proteinuria with less adverse effects on hyperkalemia, further studies are necessary to investigate the risk-benefit balance in patients with advanced CKD.

\section{Underlying mechanisms responsible for pharmaco- logical effects of MR blockers}

During the progression of renal injury, aldosterone might be involved in injuries of glomerular podocytes, the mesangium, the tubulointerstitium, and tubules through locally expressed MR. However, the precise molecular mechanisms responsible for aldosterone and MR-induced cell injury are unclear. In the kidney, aldosterone activates multiple intracellular mechanisms including reactive oxygen species (ROS) $(12,19,58)$, mitogen-activated protein kinases (MAPKs) $(12,29,59$, 60 ), and Rho-kinase (14), and so on by activating MR. These molecular mechanisms have been reviewed previously $(6,7)$, and will not be discussed in detail here. 


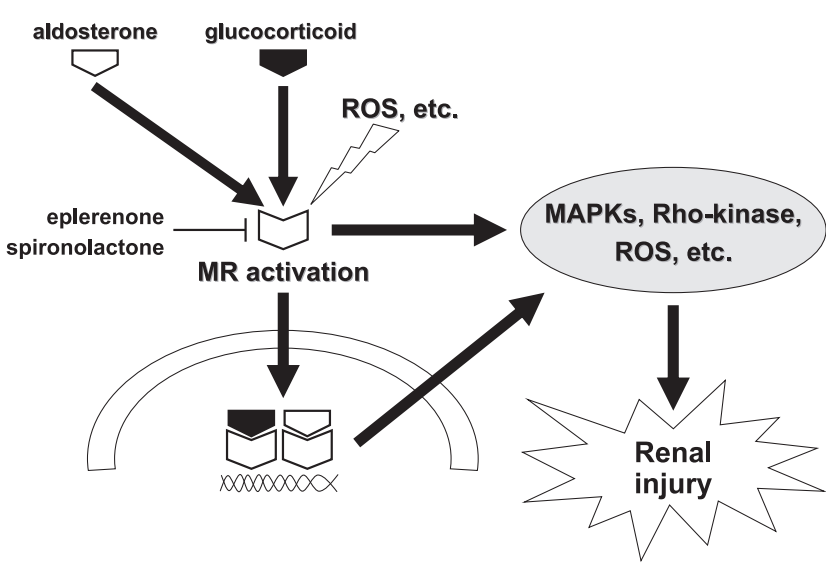

Fig. 1. Possible mechanisms of renal injury induced by mineralocorticoid receptor $(\mathrm{MR})$ activation. $\mathrm{MAPKs}=$ mitogen-activated protein kinases. $\mathrm{ROS}=$ reactive oxygen species.

In high salt-treated stroke-prone SHRs (61) and Dahl salt-sensitive hypertensive rats $(62,63)$, MR blockade with eplerenone attenuates proteinuria and renal injury, independent of blood pressure changes. However, plasma aldosterone levels were suppressed in these high salt-treated animals. Similarly, the renoprotective effects of MR blockers are often observed in patients with CKD, even when circulating aldosterone levels are normal or low. These results suggest that the renoprotective effects of MR blockers are not mediated through inhibition of aldosterone. Funder $(64,65)$ describes a possible role of normal-level glucocorticoids in activating MR, thus mediating tissue injury and ROS generation. Furthermore, increased renal tissue expression of $11 \beta$-hydroxysteroid dehydrogenase type $2(11 \beta \mathrm{HSD} 2)$ was observed in patients with CKD (11). Thus, it is possible that, during the progression of renal injury, a reduction in $11 \beta \mathrm{HSD} 2$ activity leads to occupancy of the MR by glucocorticoids such as cortisol. Alternatively, ROS may directly activate MR as recently suggested $(66,67)$. Figure 1 depicts the possible mechanisms of MR-dependent renal injury; however, it is obvious that further studies are needed to address these issues.

\section{Adverse effects of MR blockers}

Several clinical reports have indicated that treatment with MR blockers results in a dose-dependent increase in serum potassium levels (68). It has also been suggested that the frequency and the severity of hyperkalemia may be increased in certain patient populations, for example, those with diabetic nephropathy and/or severe renal failure (69). However, it should be emphasized that large clinical trials including the
Randomized Aldactone Evaluation Study (RALES) and the Eplerenone Post-Acute Myocardial Infarction Heart Failure Efficacy and Survival Study (EPHESUS) have demonstrated that hyperkalemia should not be a problem if subjects are carefully selected $(70,71)$. For example, RALES showed that the incidence of hyperkalemia did not differ between the placebo and spironolactonetreated groups (70). In this regard, Sato et al. (42) have indicated that the potassium levels are rarely problematic if subjects are picked out with the greatest possible care and followed up closely. In particular, they emphasized that adverse effects of MR blockers on serum potassium would occur if the usage recommendations based on the previous studies were not observed. Furthermore, elderly patients or those with dehydration and severe renal failure require closer monitoring or termination of MR blocker administration (42). Thus, MR blockers should be carefully prescribed by specialists for patients with CKD with a close follow-up. Other adverse effects of MR blockers including sex-hormonerelated side effects of spironolactone are well summarized by a recent review (43).

\section{Conclusions}

In this review, we briefly summarized evidence of the renoprotective effects of MR blockers. From both the preclinical and clinical evidence, it seems clear that MR blockers elicit beneficial effects in patients with CKD. However, further studies are needed to investigate the risk-benefit balance in CKD patients treated with MR blockers and ACE inhibitors and/or ARBs.

\section{Acknowledgments}

This work was supported by a Grant-in-Aid for scientific research from the Ministry of Education, Culture, Sports, Science, and Technology of Japan (20590253) and by grants from the Uehara Memorial Fundation, Japan Research Foundation for Clinical Pharmacology, and Kagawa University Project Research 2008 (to Akira Nishiyama).

\section{References}

1 Kobori H, Nangaku M, Navar LG, Nishiyama A. The intrarenal renin-angiotensin system: from physiology to the pathobiology of hypertension and kidney disease. Pharmacol Rev. 2007;59: 251-287.

2 Buse JB, Ginsberg HN, Bakris GL, Clark NG, Costa F, Eckel R, et al. Primary prevention of cardiovascular diseases in people with diabetes mellitus: a scientific statement from the American Heart Association and the American Diabetes Association. Circulation. 2007;115:114-126.

3 Mancia G, De Backer G, Dominiczak A, Cifkova R, Fagard R, Germano G, et al. 2007 Guidelines for the Management of 
Arterial Hypertension: The Task Force for the Management of Arterial Hypertension of the European Society of Hypertension (ESH) and of the European Society of Cardiology (ESC). J Hypertens. 2007;25:1105-1187.

4 Japanese Society of Hypertension guidelines for the management of hypertension (JSH 2004). Hypertens Res. 2006;29 Suppl:S1-S105.

5 Chobanian AV, Bakris GL, Black HR, Cushman WC, Green LA, Izzo JL Jr, et al. The Seventh Report of the Joint National Committee on Prevention, Detection, Evaluation, and Treatment of High Blood Pressure: the JNC 7 report. JAMA. 2003;289: 2560-2572.

6 Nishiyama A, Abe Y. Molecular mechanisms and therapeutic strategies of chronic renal injury: renoprotective effects of aldosterone blockade. J Pharmacol Sci. 2006;100:9-16.

7 Kiyomoto H, Rafiq K, Mostofa M, Nishiyama A. Possible underlying mechanisms responsible for aldosterone and mineralocorticoid receptor-dependent renal injury. J Pharmacol Sci. 2008:108;399-405.

8 Halimi JM, Mimran A. Albuminuria in untreated patients with primary aldosteronism or essential hypertension. J Hypertens. 1995;13:1801-1802.

9 Nishimura M, Uzu T, Fujii T, Kuroda S, Nakamura S, Inenaga T, et al. Cardiovascular complications in patients with primary aldosteronism. Am J Kidney Dis. 1999;33:261-266.

10 Bianchi S, Bigazzi R, Campese VM. Antagonists of aldosterone and proteinuria in patients with CKD: an uncontrolled pilot study. Am J Kidney Dis. 2005;46:45-51.

11 Quinkler M, Zehnder D, Eardley KS, Lepenies J, Howie AJ, Hughes SV, et al. Increased expression of mineralocorticoid effector mechanisms in kidney biopsies of patients with heavy proteinuria. Circulation. 2005;112:1435-1443.

12 Nishiyama A, Yao L, Nagai Y, Miyata K, Yoshizumi M, Kagami $\mathrm{S}$, et al. Possible contributions of reactive oxygen species and mitogen-activated protein kinase to renal injury in aldosterone /salt-induced hypertensive rats. Hypertension. 2004;43:841848.

13 Fan YY, Baba R, Nagai Y, Miyatake A, Hosomi N, Kimura S, et al. Augmentation of intrarenal angiotensin II levels in uninephrectomized aldosterone/salt-treated hypertensive rats; renoprotective effects of an ultrahigh dose of olmesartan. Hypertens Res. 2006;29:169-178.

14 Sun GP, Kohno M, Guo P, Nagai Y, Miyata K, Fan YY, et al. Involvements of Rho-kinase and TGF-beta pathways in aldosterone-induced renal injury. J Am Soc Nephrol. 2006;17: 2193-2201.

15 Fujisawa G, Okada K, Muto S, Fujita N, Itabashi N, Kusano E, et al. Spironolactone prevents early renal injury in streptozotocininduced diabetic rats. Kidney Int. 2004;66:1493-1502.

16 Liu YJ, Nakagawa Y, Toya K, Wang Y, Saegusa H, Nakanishi T, et al. Effects of spironolactone on systolic blood pressure in experimental diabetic rats. Kidney Int. 2000;57:2064-2071.

17 Han KH, Kang YS, Han SY, Jee YH, Lee MH, Han JY, et al. Spironolactone ameliorates renal injury and connective tissue growth factor expression in type II diabetic rats. Kidney Int. 2006;70:111-120.

18 Guo C, Martinez-Vasquez D, Mendez GP, Toniolo MF, Yao TM, Oestreicher EM, et al. Mineralocorticoid receptor antagonist reduces renal injury in rodent models of types 1 and 2 diabetes mellitus. Endocrinology. 2006;147:5363-5373.
19 Nagase M, Matsui H, Shibata S, Gotoda T, Fujita T. Salt-induced nephropathy in obese spontaneously hypertensive rats via paradoxical activation of the mineralocorticoid receptor: role of oxidative stress. Hypertension. 2007;50:877-883.

20 Monrad SU, Killen PD, Anderson MR, Bradke A, Kaplan MJ. The role of aldosterone blockade in murine lupus nephritis. Arthritis Res Ther. 2008;10:R5.

21 Rocha R, Stier CT Jr, Kifor I, Ochoa-Maya MR, Rennke HG, Williams GH, et al. Aldosterone: a mediator of myocardial necrosis and renal arteriopathy. Endocrinology. 2000;141:38713878.

22 Bobadilla NA, Gamba G. New insights into the pathophysiology of cyclosporine nephrotoxicity: a role of aldosterone. Am J Physiol Renal Physiol. 2007;293:F2-F9.

23 Perez-Rojas J, Blanco JA, Cruz C, Trujillo J, Vaidya VS, Uribe $\mathrm{N}$, et al. Mineralocorticoid receptor blockade confers renoprotection in preexisting chronic cyclosporine nephrotoxicity. Am J Physiol Renal Physiol. 2007;292:F131-F139.

24 Feria I, Pichardo I, Juarez P, Ramirez V, Gonzalez MA, Uribe N, et al. Therapeutic benefit of spironolactone in experimental chronic cyclosporine A nephrotoxicity. Kidney Int. 2003;63:4352.

25 Brown NJ, Nakamura S, Ma L, Nakamura I, Donnert E, Freeman $\mathrm{M}$, et al. Aldosterone modulates plasminogen activator inhibitor1 and glomerulosclerosis in vivo. Kidney Int. 2000;58:12191227.

26 Trachtman H, Weiser AC, Valderrama E, Morgado M, Palmer LS. Prevention of renal fibrosis by spironolactone in mice with complete unilateral ureteral obstruction. J Urol. 2004;172:1590 1594.

27 Mejia-Vilet JM, Ramirez V, Cruz C, Uribe N, Gamba G, Bobadilla NA. Renal ischemia-reperfusion injury is prevented by the mineralocorticoid receptor blocker spironolactone. Am J Physiol Renal Physiol. 2007;293:F78-F86.

28 Aldigier JC, Kanjanbuch T, Ma LJ, Brown NJ, Fogo AB. Regression of existing glomerulosclerosis by inhibition of aldosterone. J Am Soc Nephrol. 2005;16:3306-3314.

29 Nishiyama A, Yao L, Fan Y, Kyaw M, Kataoka N, Hashimoto K, et al. Involvement of aldosterone and mineralocorticoid receptors in rat mesangial cell proliferation and deformability. Hypertension. 2005;45:710-716.

30 Shibata S, Nagase M, Yoshida S, Kawachi H, Fujita T. Podocyte as the target for aldosterone: roles of oxidative stress and Sgk1. Hypertension. 2007;49:355-364.

31 Nagai Y, Miyata K, Sun GP, Rahman M, Kimura S, Miyatake A, et al. Aldosterone stimulates collagen gene expression and synthesis via activation of ERK1/2 in rat renal fibroblasts. Hypertension. 2005;46:1039-1045.

32 Patni H, Mathew JT, Luan L, Franki N, Chander PN, Singhal PC. Aldosterone promotes proximal tubular cell apoptosis: role of oxidative stress. Am J Physiol Renal Physiol. 2007;293: F1065-F1071.

33 Rachmani R, Slavachevsky I, Amit M, Levi Z, Kedar Y, Berla $\mathrm{M}$, et al. The effect of spironolactone, cilazapril and their combination on albuminuria in patients with hypertension and diabetic nephropathy is independent of blood pressure reduction: a randomized controlled study. Diabet Med. 2004;21:471-475.

34 Williams GH, Burgess E, Kolloch RE, Ruilope LM, Niegowska J, Kipnes MS, et al. Efficacy of eplerenone versus enalapril as monotherapy in systemic hypertension. Am J Cardiol. 2004;93: 
990-996.

35 White WB, Duprez D, St Hillaire R, Krause S, Roniker B, KuseHamilton J, et al. Effects of the selective aldosterone blocker eplerenone versus the calcium antagonist amlodipine in systolic hypertension. Hypertension. 2003;41:1021-1026.

36 Sato A, Saruta T. Aldosterone breakthrough during angiotensinconverting enzyme inhibitor therapy. Am J Hypertens. 2003;16: 781-788.

37 Xiao F, Puddefoot JR, Vinson GP. Aldosterone mediates angiotensin II-stimulated rat vascular smooth muscle cell proliferation. J Endocrinol. 2000;165:533-536.

38 Mazak I, Fiebeler A, Muller DN, Park JK, Shagdarsuren E, Lindschau C, et al. Aldosterone potentiates angiotensin IIinduced signaling in vascular smooth muscle cells. Circulation. 2004;109:2792-2800.

39 Min LJ, Mogi M, Li JM, Iwanami J, Iwai M, Horiuchi M. Aldosterone and angiotensin II synergistically induce mitogenic response in vascular smooth muscle cells. Circ Res. 2005;97: 434-442.

40 Min LJ, Mogi M, Iwanami J, Li JM, Sakata A, Fujita T, et al. Cross-talk between aldosterone and angiotensin II in vascular smooth muscle cell senescence. Cardiovasc Res. 2007;76:506516.

41 Montezano AC, Callera GE, Yogi A, He Y, Tostes RC, He G, et al. Aldosterone and Angiotensin II Synergistically Stimulate Migration in Vascular Smooth Muscle Cells Through c-SrcRegulated Redox-Sensitive RhoA Pathways. Arterioscler Thromb Vasc Biol. 2008;28:1511-1518.

42 Sato A, Saruta T, Funder JW. Combination therapy with aldosterone blockade and renin-angiotensin inhibitors confers organ protection. Hypertens Res. 2006;29:211-216.

43 Takeda Y. Pleiotropic actions of aldosterone and the effects of eplerenone, a selective mineralocorticoid receptor antagonist. Hypertens Res. 2004;27:781-789.

44 Schjoedt KJ, Rossing K, Juhl TR, Boomsma F, Rossing P, Tarnow L, et al. Beneficial impact of spironolactone in diabetic nephropathy. Kidney Int. 2005;68:2829-2836.

45 Furumatsu Y, Nagasawa Y, Tomida K, Mikami S, Kaneko T, Okada N, et al. Effect of renin-angiotensin-aldosterone system triple blockade on non-diabetic renal disease: addition of an aldosterone blocker, spironolactone, to combination treatment with an angiotensin-converting enzyme inhibitor and angiotensin II receptor blocker. Hypertens Res. 2008;31:59-67.

46 Bomback AS, Kshirsagar AV, Amamoo MA, Klemmer PJ. Change in proteinuria after adding aldosterone blockers to ACE inhibitors or angiotensin receptor blockers in CKD: a systematic review. Am J Kidney Dis. 2008;51:199-211.

47 van den Meiracker AH, Baggen RG, Pauli S, Lindemans A, Vulto AG, Poldermans D, et al. Spironolactone in type 2 diabetic nephropathy: Effects on proteinuria, blood pressure and renal function. J Hypertens. 2006;24:2285-2292.

48 Bianchi S, Bigazzi R, Campese VM. Long-term effects of spironolactone on proteinuria and kidney function in patients with chronic kidney disease. Kidney Int. 2006;70:2116-2123.

49 Chrysostomou A, Pedagogos E, MacGregor L, Becker GJ. Double-blind, placebo-controlled study on the effect of the aldosterone receptor antagonist spironolactone in patients who have persistent proteinuria and are on long-term angiotensinconverting enzyme inhibitor therapy, with or without an angiotensin II receptor blocker. Clin J Am Soc Nephrol. 2006;1:256-
262.

50 Epstein M, Williams GH, Weinberger M, Lewin A, Krause S, Mukherjee R, et al. Selective aldosterone blockade with eplerenone reduces albuminuria in patients with type 2 diabetes. Clin J Am Soc Nephrol. 2006;1:940-951.

51 Schjoedt KJ, Rossing K, Juhl TR, Boomsma F, Tarnow L, Rossing P, et al. Beneficial impact of spironolactone on nephrotic range albuminuria in diabetic nephropathy. Kidney Int. 2006;70:536-542.

52 Rossing K, Schjoedt KJ, Smidt UM, Boomsma F, Parving HH. Beneficial effects of adding spironolactone to recommended antihypertensive treatment in diabetic nephropathy: a randomized, double-masked, cross-over study. Diabetes Care. 2005;28:21062112.

53 Chrysostomou A, Becker G. Spironolactone in addition to ACE inhibition to reduce proteinuria in patients with chronic renal disease. N Engl J Med. 2001;345:925-926.

54 Nowicki M, Muskala P, Bald E, Chwatko G. Nephroprotective effect of combined converting enzyme and aldosterone blockade in hypertensive patients with target organ damage is blood pressure-dependent. J Am Soc Nephrol. 2003(Abstr);14:21A.

55 Shiigai T, Kuwana H, Kobayashi T, Maeda Y. Effect of spironolactone added to angiotensin receptor blocker in renal failure patients. J Am Soc Nephrol. 2003(Abstr);14:763A.

56 Nitta K, Uchida K, Nihei H. Spironolactone and angiotensin receptor blocker in nondiabetic renal diseases. Am J Med. 2004;117:444-445.

57 Sato A, Hayashi K, Saruta T. Antiproteinuric effects of mineralocorticoid receptor blockade in patients with chronic renal disease. Am J Hypertens. 2005;18:44-49.

58 Miyata K, Rahman M, Shokoji T, Nagai Y, Zhang GX, Sun GP, et al. Aldosterone stimulates reactive oxygen species production through activation of NADPH oxidase in rat mesangial cells. J Am Soc Nephrol. 2005;16:2906-2912.

59 Terada Y, Kobayashi T, Kuwana H, Tanaka H, Inoshita S, Kuwahara M, et al. Aldosterone stimulates proliferation of mesangial cells by activating mitogen-activated protein kinase 1/2, cyclin D1, and cyclin A. J Am Soc Nephrol. 2005;16:22962305 .

60 Terada Y, Kuwana H, Kobayashi T, Okado T, Suzuki N, Yoshimoto $\mathrm{T}$, et al. Aldosterone-stimulated SGK1 activity mediates profibrotic signaling in the mesangium. J Am Soc Nephrol. 2008;19:298-309.

61 Rocha R, Chander PN, Khanna K, Zuckerman A, Stier CT Jr. Mineralocorticoid blockade reduces vascular injury in strokeprone hypertensive rats. Hypertension. 1998;31:451-458.

62 Kobayashi N, Hara K, Tojo A, Onozato ML, Honda T, Yoshida $\mathrm{K}$, et al. Eplerenone shows renoprotective effect by reducing LOX-1-mediated adhesion molecule, PKCepsilon-MAPKp90RSK, and Rho-kinase pathway. Hypertension. 2005;45:538544.

63 Nagase M, Shibata S, Yoshida S, Nagase T, Gotoda T, Fujita T. Podocyte injury underlies the glomerulopathy of Dahl salthypertensive rats and is reversed by aldosterone blocker. Hypertension. 2006;47:1084-1093.

64 Funder JW. The role of aldosterone and mineralocorticoid receptors in cardiovascular disease. Am J Cardiovasc Drugs. 2007;7:151-157.

65 Funder JW. Why are mineralocorticoid receptors so nonselective? Curr Hypertens Rep. 2007;9:112-116. 
66 Shibata S, Nagase M, Yoshida S, Kawarazaki W, Kurihara H, Tanaka $\mathrm{H}$, et al. Modification of mineralocorticoid receptor function by Rac1 GTPase: implication in proteinuric kidney disease. Nat Med. 2008;14:1370-1376.

67 Wang H, Shimosawa T, Matsui H, Kaneko T, Ogura S, Uetake Y, et al. Paradoxical mineralocorticoid receptor activation and left ventricular diastolic dysfunction under high oxidative stress conditions. J Hypertens. 2008;26:1453-1462.

68 McMahon EG. Recent studies with eplerenone, a novel selective aldosterone receptor antagonist. Curr Opin Pharmacol. 2001;1: 190-196.

69 Sica DA. Eplerenone: a new aldosterone receptor antagonist - are the FDAs restrictions appropriate? J Clin Hypertens (Greenwich). 2002;4:441-445.

70 Pitt B, Zannad F, Remme WJ, Cody R, Castaigne A, Perez A, et al. The effect of spiornolactone on morbidity and mortality in patients with severe heart failure. Randomized Aldactone Evaluation Study Investigators. N Engl J Med. 1999;341:709 717.

71 Pitt B, Remme W, Zannad F, Neaton J, Martinez F, Roniker B, et al. Eplerenone, a selective aldosterone blocker, in patients with left ventricular dysfunction after myocardial infarction. $\mathrm{N}$ Engl J Med. 2003;348:1309-1321. 